\title{
Blood Pressure Modulation and Cardiovascular Protection by Melatonin: Potential Mechanisms Behind
}

\author{
L. PAULIS ${ }^{1,2,3}$, F. ŠIMKO ${ }^{1,2,4}$ \\ ${ }^{1}$ Institute of Pathophysiology, School of Medicine, Comenius University, Bratislava, ${ }^{2}$ Institute of \\ Normal and Pathological Physiology, Slovak Academy of Sciences, Bratislava, ${ }^{3}$ Institute of \\ Physiology, Academy of Sciences of the Czech Republic, Prague, Czech Republic and ${ }^{4}$ Third Clinic \\ of Medicine, School of Medicine, Comenius University, Bratislava, Slovak Republic
}

Received March 1, 2007

Accepted August 21, 2007

\begin{abstract}
Summary
The production of the pineal hormone melatonin is synchronized with day-night cycle via multisynaptic pathway including suprachiasmatic nucleus linking several physiological functions to diurnal cycle. The recent data indicate that impaired melatonin production is involved in several cardiovascular pathologies including hypertension and ischemic heart disease. However, the mechanisms of melatonin effect on cardiovascular system are still not completely understood. The activation of melatonin receptors on endothelial and vascular smooth muscle cells and antioxidant properties of melatonin could be responsible for the melatonin effects on vascular tone. However, the data from in vitro studies are controversial making the explanation of the melatonin effect on blood pressure in vivo difficult. In vivo, melatonin also attenuates sympathetic tone by direct activation of melatonin receptors, scavenging free radicals or increasing NO availability in the central nervous system. The central and peripheral antiadrenergic action of chronic melatonin treatment might eliminate the mechanisms counter-regulating decreased blood pressure, providing thus additional cardioprotective mechanism. The extraordinary antioxidant activity and antilipidemic effects of melatonin may enhance the modulation of blood pressure by melatonin and probably play the most important role in the amelioration of target organ damage by chronic melatonin treatment. Further investigation of these mechanisms should provide novel knowledge about pathophysiological mechanisms of cardiovascular diseases, additional explanation for their circadian and seasonal variability and potentially generate new impulses for the development of therapeutic arsenal.
\end{abstract}

Key words

Melatonin $\bullet$ Hypertension $\bullet$ Nitric oxide $\bullet$ Free radicals $\bullet$ Sympathetic nervous system

\section{Introduction}

Since the identification of melatonin by Lerner et al. (1958), it has been shown, that melatonin is involved in the regulation of many physiological systems, including cardiovascular system (Važan et al. 2003, 2004). Melatonin influences blood pressure (Arangino et al. 1999), myocardial contractility (Abete et al. 1997) and 
increases the antioxidant reserve (Girouard et al. 2004). Melatonin receptors were discovered in the heart (Pang et al. 2002) and arteries (Masana et al. 2002). Moreover, decreased melatonin levels were reported in various pathological conditions including hypertension with nondipper pattern (Jonas et al. 2003), impairment of heart failure (Girotti et al. 2003), ischemic heart disease (Brugger et al. 1995), or in patients after acute myocardial infarction (Dominguez-Rodriguez et al. 2002). Melatonin is often available as dietary supplement without need of medical prescription, what increases the chance of regular melatonin intake by patients suffering from a cardiovascular disease. Therefore, melatonin is coming to the cutting edge of cardiovascular research and its effects on cardiovascular system in clinical situation are being discussed (Šimko and Paulis 2007). However, results obtained on models with different analytical level are partially controversial and the mechanisms behind melatonin influence on cardiovascular system are still not completely understood.

In this review we have summarized and confronted data from studies on isolated cells, animal experiments as well as small clinical trials. Our major aim was to suggest important mechanisms and pathways that might be responsible for the physiological and clinical importance of melatonin in the cardiovascular system. We paid special attention to the regulation of blood pressure, one of the most important determinants of cardiovascular risk. Moreover, we focused on melatonin impact on cardiovascular remodeling and myocardial reperfusion injury. The details about protection against damage to the brain (Reiter et al. 2005) or kidney (Tylicki et al. 2003) by melatonin represent, however, an extensive topic and are behind the scope of this review.

\section{Background}

The regulation of melatonin synthesis and melatonin concentrations

Melatonin, an endocrine product of the pineal gland, is formed predominantly during night-time. Light has an inhibitory effect on pineal melatonin secretion (Wurtman et al. 1964). Melatonin release is synchronized with day-light cycle by a multisynaptic pathway. Light stimulates retina to modulate the activity of suprachiasmatic nucleus (SCN) (Moore 1996), the site of the master biological clock (Dubocovich et al. 1998). GABA-ergic neurons are projected from $\mathrm{SCN}$ to paraventricular nucleus (PVN) (Moore 1996) intermittently inhibiting the constant excitatory output for sympathetic intermediolateral nucleus (Kalsbeek et al. 2000). The sympathetic stimulation from intermediolateral nucleus is after interpolation in superior cervical ganglion finally directed to the epiphysis to induce melatonin synthesis (Moore 1996). The activity of rate limiting enzymes in the epiphysis is regulated by norepinephrine binding to pineal $\beta_{1}$ - and $\alpha_{1}$-adrenoceptors (Klein et al. 1983, Reiter 1991, Ribelayga et al. 1997). Moreover, other neurohumoral systems, e.g. the local renin-angiotensin system, may modify melatonin secretion as well (Baltatu et al. 2002). The interference of melatonin synthesis and action with other neurohumoral systems plays an important role in the modulation of cardiovascular functions by melatonin. The concentrations of melatonin in the sera of healthy subjects reach $10^{-10}$ to $10^{-9} \mathrm{~mol} / \mathrm{l}$ during the night and an order lower value during the day (Kennaway and Voultsios 1998). It should be noted, that physiological blood levels of melatonin do not reach peak concentrations achieved by pharmacological application (10 $10^{-7}$ to $10^{-5} \mathrm{~mol} / 1$ after $60-150 \mathrm{~min}$ ) (Waldhauser et al. 1984, DeMuro et al. 2000).

\section{Specific mechanisms of melatonin effects}

Many authors suppose that melatonin acts mainly via its membrane receptors (Costa et al. 1995). However, melatonin's lipophilic nature allows it to act also intracellularly i.e. on its nuclear receptor (Mor et al. 1999).

Since the identification of melatonin binding site (Vaneček et al. 1987), two G-protein-coupled melatonin membrane receptor subtypes have been identified in mammals: $\mathrm{MT}_{1}$ (formerly Mel 1a or $\mathrm{mt}_{1}$ ) and $\mathrm{MT}_{2}$ (Mel 1b) (Dubocovich et al. 1998). The $\mathrm{MT}_{1}$ receptor was shown to associate with various second messengers: $\mathrm{G}_{\mathrm{i}}$-coupled decrease in cyclic AMP levels (Capsoni et al. 1994, Reppert et al. 1996, Witt-Enderby and Duboccovich 1996), $\mathrm{G}_{\mathrm{q}}$-coupled phospholipase-C activation resulting in increased cytosolic $\mathrm{Ca}^{2+}$ (Brydon et al. 1999) or G-coupled activation of the Kir 3 K-channels (Nelson et al. 1996). $\mathrm{MT}_{2}$ receptor was demonstrated to couple with $\mathrm{G}_{\mathrm{q}}$-protein mediated phosphatidylinositol4,5-bisphosphate hydrolysis (Dubocovich 1995). The third receptor type $\mathrm{MT}_{3}$, which has a lower affinity, is probably not coupled with G protein (Mor et al. 1999).

The highest density of melatonin receptors was shown to be in central nervous system, particularly in the adenohypophysis (Williams and Morgan 1988, Malpaux 
et al. 1995, 2001), SCN (Vaneček et al. 1987, Vaneček and Janský 1989), PVN (Duncan et al. 1989) and area postrema (Williams et al. 1995). In the cardiovascular system melatonin receptors were first revealed in 1990 in rat caudal artery (Viswanathan et al. 1990). $\mathrm{MT}_{1}$-receptor was identified in chicken (Pang et al. 2002) and human (Ekmekcioglu et al. 2001) coronary arteries as well as in chicken (Pang et al. 1993) and rat (Abete et al. 1997) heart, whereas $\mathrm{MT}_{2}$-receptor in the human heart, coronary arteries and the aorta (Ekmekcioglu et al. 2003). The precise localization of these receptors is not completely revealed. It was hypothesized that while $\mathrm{MT}_{1}$-receptor is localized primary on vascular smooth muscle cells, the $\mathrm{MT}_{2}$-receptor appears on endothelial as well as vascular smooth muscle cells (Masana et al. 2002).

\section{Non-specific mechanisms of melatonin effects}

Despite the high density of melatonin receptors in the central nervous system, and on the periphery as well, other mechanisms of melatonin action independent on specific receptors have been reported.

The antioxidant properties of melatonin, especially in pharmacological doses seem to be the most pronounced (Ianas et al. 1991). Melatonin was able to reduce lipid peroxidation more effectively than vitamin $\mathrm{C}$ or E (Gitto et al. 2001). The potent antioxidant ability can be explained by the potential to scavenge hydroxyl (Bromme et al. 2000), superoxide (Sewerynek et al. 1996), peroxyl (Pieri et al. 1994) but also NO (Noda et al. 1999) free radical. The reported NO scavenging could have adverse effects on cardiovascular system. Okatani et al. (2001) attributed the vasoconstriction of the human umbilical artery observed after melatonin administration to the potential of melatonin to scavenge NO. However, vasoconstriction was seen only at high melatonin concentrations (Okatani et al. 2001) and in vitro experiments have shown that melatonin scavenges NO only in the presence of oxygen and it possibly interacts with peroxynitrite rather than $\mathrm{NO}$ alone (Blanchard et al. 2000). The antioxidant activity of melatonin is enhanced by the induction of antioxidant enzymes (Antolin et al. 1996, Barlow-Walden et al. 1995), the stability of the oxidized form of melatonin (Kojšová et al. 2006) and high free radical scavenging activity of melatonin metabolites as well (Tan et al. 2007). The antioxidant properties of melatonin in vivo are demonstrated by the ability of melatonin to reduce ischemia-reperfusion injury in various organs, including the heart (Tan et al. 1998), kidney (Sahna et al. 2003), brain (Cho et al. 1997) and liver (Sewerynek et al. 1996).

Non-specific mechanisms of melatonin action can also reside in direct interaction with calmodulin (Turjanski et al. 2004), inhibition of $\mathrm{Ca}^{2+}$ channels (Satake et al. 1986, Shibata et al. 1989) or calcium pump stimulation observed in cardiomyocytes (Chen et al. 1993). In the central nervous system the ability of melatonin to bind and activate GABA-receptors (Wang et al. 2003) along with its ability to reduce oxidative load and to enhance NO signaling may also participate in the central regulation of sympathetic tone.

\section{Melatonin and blood pressure}

Since hypertension is one of the most prevalent and pronounced risk factors for various cardiovascular alterations, the effect of melatonin on blood pressure deserves special attention among its influence on cardiovascular system.

\section{Experimental hypertension}

In experimental conditions the surgical removal of epiphysis, pinealectomy, which was associated with decreased melatonin production, caused vasoconstriction (Cunnane et al. 1980), unchanged cardiac output (Harlow 1987) and temporary hypertension in adult rats (Zanoboni and Zanoboni-Mucciaci 1967, Zanoboni et al. 1978). Administration of melatonin reversed pinealectomyinduced hypertension (Holmes and Sudgen 1976). The exposure of experimental animals to continuous light (24 hours/day), which prevented the nocturnal rise of melatonin serum levels (Brown et al. 1991), also resulted in suppression of circadian heart rate and blood pressure variability (Briaud et al. 2004). Therefore under the experimental conditions it could be even spoken about "melatonin-deficient" hypertension.

In spontaneously hypertensive rats (SHR) melatonin production was shown to decline with aging more rapidly than in normotensive rats (Kawashima et al. 1987). The pharmacological treatment with melatonin for five days in adult SHR resulted in graduate decrease in blood pressure, heart rate and plasma renin activity (Kawashima et al. 1987). Although in some studies melatonin administration to SHR reverted established hypertension only partially (Pechán̆ová et al. 2007), its antihypertensive effect was more pronounced than the effect of the antioxidant N-acetylcysteine (Kojšová et al. 2006) and was comparable with the effect of spironolactone (Paulis et al. 2006). 
In another experiment in melatonin-treated SHR, the reduction of blood pressure and heart rate was associated with increased endothelium-dependent vasodilatation and increased sensitivity to NO-synthase inhibitor (Girouard et al. 2001) suggesting improved NO signaling. This hypothesis is also supported by the observation of increased cytosolic $\mathrm{Ca}^{2+}$ levels in endothelial cells (Pogan et al. 2002), which may result in increased NO production via enhancement of NOsynthase activity, increased cyclic GMP levels and decreased intracellular $\mathrm{Ca}^{2+}$ in smooth muscle cells with subsequent vasodilatation (Anwar et al. 2001). Interestingly, the antioxidant $\mathrm{N}$-acetylcysteine reduced blood pressure, heart rate and catecholamine concentration and $\beta$-adrenoceptor expression (both impaired in SHR) in a similar level as melatonin (Girouard et al. 2003). Moreover, the decreased blood pressure and improved baroreflex in SHR correlated with improved antioxidant capacity after long-term melatonin administration (Girouard et al. 2004) suggesting an association of antioxidant melatonin properties with its ability to decrease sympathetic tone.

Acute administration of melatonin lowered blood pressure and reduced norepinephrine blood levels in SHR (K-Laflamme et al. 1998). In vitro, melatonin attenuated constriction of aortic ring in SHR by inhibiting phospholipase C cascade independently on MT-receptor or $\alpha_{1}$-adrenoceptor blockade (K-Laflamme et al. 1998). Since similar inhibitory effect was also achieved with an antioxidant enzyme superoxide dismutase, it might be assumed that the beneficial effect of melatonin was mediated by its ability to prevent excess oxidative load, which was reported to contribute to enhanced vasoconstriction in spontaneous hypertension ( $\mathrm{Wu}$ et al. 1998).

\section{Melatonin in normotensive and hypertensive humans}

The blood pressure lowering effect of melatonin was reported in healthy women receiving contraception (Cagnacci et al. 1997), postmenopausal women on hormonal substitution therapy (Cagnacci et al. 2001) and healthy men (Arangino et al. 1999). The reduction of blood pressure after acute melatonin administration was associated with reduced norepinephrine levels and pulse index (Cagnacci et al. 1998). The unchanged heart rate and decreased pulse index in these experiments indicate that the blood pressure decrease after melatonin is in vivo mediated by attenuation of the peripheral resistance achieved potentially by increased NO formation
(Cagnacci et al. 2001).

Impaired circadian rhythm of autonomic tone was observed in several studies on hypertension (Guzzetti et al. 1991, Nakano et al. 2001). This phenomenon was associated with disturbed neurotransmission in suprachiasmatic nucleus as proven on humans post-mortem (Goncharuk et al. 2001), which is the regulatory center for melatonin secretion (Klein and Weller 1972) and autonomic tone (Scheer et al. 1999, 2001). Decreased nocturnal melatonin concentrations were observed in patients with non-dipping blood profile (Zeman et al. 2005). Although in a double-blind randomized cross-over study acute melatonin administration failed to influence blood pressure, chronic 3-week melatonin administration reduced blood pressure and amplified the night time blood pressure decrease (Scheer et al. 2004). The authors explained the inability of melatonin to decrease blood pressure after acute administration by the possible involvement of SCN. While in previous studies melatonin was reported to decrease blood pressure after administration during day-time when the SCN activity is high, in this study melatonin was given before sleep onset, when the SCN activity is low and further inhibition is hardly possible. On the other hand, the long-term regular intake before sleep supported normal rhythm in melatonin concentrations and was therefore effective in restoring circadian variability in blood pressure (Scheer et al. 2004).

\section{The mechanisms of the effect of melatonin on blood pressure}

From the mechanistic point of view, blood pressure is the function of cardiac output and peripheral resistance. Studies aimed to investigate the direct influence of melatonin on vascular reactivity were performed in various laboratories. However, the data obtained from these experiments are partly contradictory. Melatonin was reported to have no effect on basal arterial tone (Monroe and Watts 1998), to cause vasoconstriction (Doolen et al. 1998) or to cause vasodilatation (Weekly 1991, 1993).

Also the correlation of these findings with known intracellular pathways mediating the effects of melatonin remains controversial. The constrictive effect of melatonin can be explained by receptor mediated decrease in cyclic AMP levels (Capsoni et al. 1994, WittEnderby and Dubocovich 1996) and phosphatidylinositol-4,5-bisphosphate hydrolysis which was reported 


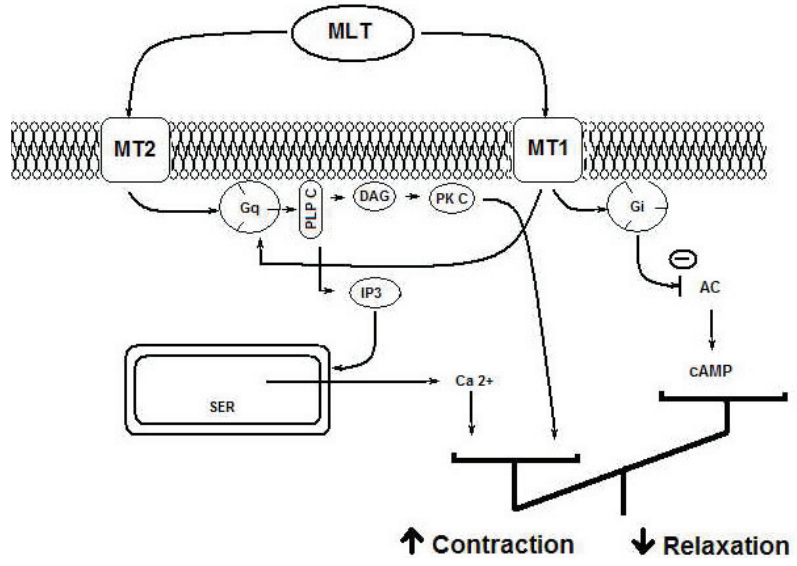

Fig. 1. Potential pathways directly mediating melatonin-induced vasoconstriction in vitro. Melatonin resceptors associated with $\mathrm{G}$ and $\mathrm{G}_{\mathrm{q}}$ proteins decrease cyclic AMP levels (Capsoni et al. 1994, Witt-Enderby and Dubocovich 1996) and stimulate phosphatidylinositol-4,5-bisphosphate hydrolysis (Dubocovich 1995). Activation of melatonin receptors on vascular smooth muscle cells should therefore diminish vasodilatation or enhance vasoconstriction. MLT, melatonin, MT1, MT2, melatonin receptor $\mathrm{MT}_{1}, \mathrm{MT}_{2}$, respectively, Gq, Gi, G-proteins, PLP C, phospholipase C, DAG, diacylglycerol, PK C, protein kinase C, IP3, inositol-1,4,5trisphosphate, SER, smooth endoplasmatic reticulum, CAMP, cyclic adenosine monophosphate.

by several in vitro studies (Dubocovich 1995) (Fig. 1).

Despite the fact that the vasodilatation after melatonin is congruent with decreased blood pressure after melatonin administration, it is difficult to explain it on the basis of melatonin receptor stimulation. The activation of melatonin receptors in the majority of experimental models was associated with cyclic AMP decrease and phosphatidylinositol-4,5-bisphosphate hydrolysis, which lead to inhibition of vasodilatation or to vasoconstriction. Nevertheless, the activation of $\mathrm{MT}_{2}$ receptors on endothelial cells (Masana et al. 2002) could increase cytosolic $\mathrm{Ca}^{2+}$ in endothelial cells, which was observed by Pogan et al. (2002). Activated endothelial cells are then stimulated to increase the production of NO, which is additionally protected by antioxidant properties of melatonin. This hypothesis is supported by the findings of Anwar et al. (2001) who observed decreased oxidative load and increased NO in blood serum associated with decreased cytosolic $\mathrm{Ca}^{2+}$ and increased cyclic GMP in vascular smooth muscle cells (Fig. 2).

The consistent results of melatonin influence on blood pressure from in vivo experiments and clinical trials are in contrast with inconsistent data from in vitro experiments and suggest the involvement of central regulatory mechanisms in the mediation of melatonin effects on blood pressure in vivo. Improved baroreflex responses (Girouard et al. 2004), decreased sympathetic

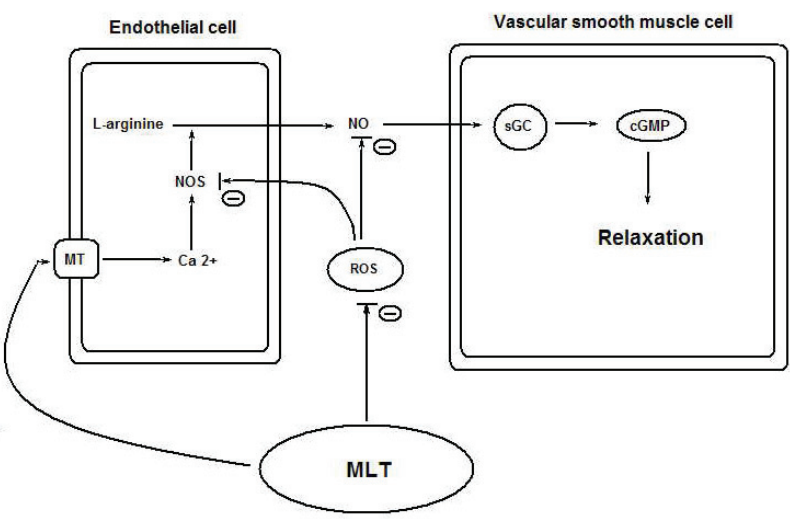

Fig. 2. Possible pathways mediating melatonin-induced vasodilatation. The activation of $\mathrm{MT}_{2}$ receptors on endothelial cells could increase cytosolic $\mathrm{Ca}^{2+}$ in endothelial cells (Pogan et al. 2002). Activated endothelial cells are stimulated to NO production. Antioxidant action of melatonin may further enhance the formation and availability of NO, which stimulates guanylate cyclase in smooth muscle cells leading to vasodilatation. MT, melatonin receptors, NOS, NO-synthase, ROS, reactive oxygen species, sCG, solubile guanylate cyclase, cGMP, cyclic guanosine monophosphate.

output (K-Laflamme et al. 1998) and association of decreased heart rate or cardiac output with blood pressure fall after melatonin administration (Kawashima et al. 1987, Arangino et al. 1999, Scheer et al. 2003) support the idea of central action of melatonin.

Although, the mechanisms participating in central effect of melatonin are yet not completely known, several pathways can be suggested:

First, neurons in PVN directly or after interpolation in rostral ventrolateral medulla (RVLM) project to medullar intermediolateral nucleus, which innervates sympathetic ganglia generating thus sympathetic tone and regulating arterial pressure (Coote et al. 1998, Pyner and Coote 2000, Cano et al. 2001, 2004, Stocker et al. 2006). The constant excitatory output of PVN is intermittently inhibited by GABA-ergic innervation from SCN (Kalsbeek et al. 2000), which enables circadian oscillations in sympathetic output synchronized with day-light (Buijs et al. 1999, Scheer et al. 2003). The same sites (SCN, PVN, intermedioalteral nucleus) are also responsible for the excitation of sympathetic neurons in the superior cervical ganglion that regulates pineal melatonin synthesis (Moore 1996). It could be hypothesized that the modulation of SCN activity by melatonin (Reppert et al. 1988, Dubocovich et al. 1998) alters sympathetic tone and thus represents a protective mechanism against excessive sympathetic excitation. Moreover, neurons in area postrema were suggested to be epigenetically modified by melatonin (Irmak and Sizlan 2006). These neurons are believed to 


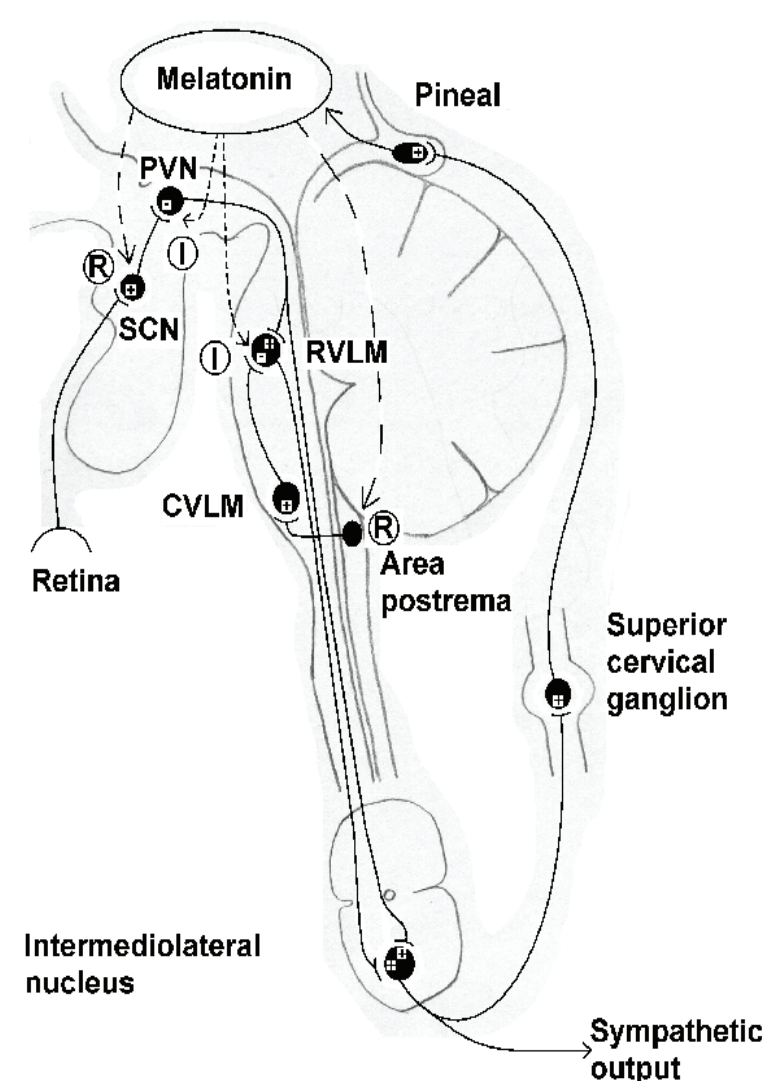

Fig. 3. Possible modulation of central sympathetic tone mediating melatonin effect on blood pressure. First, melatonin may bind to its receptors especially in SCN and area postrema, which show an especially high receptor density (Vaneček et al. 1987, Williams et al. 1995). Second, melatonin may enhance inhibitory GABA (Wang et al. 2003) and NO (Rossi et al. 2004) signalization in the PVN and RVLM (Patel et al. 2001). SCN, suprachiasmatic nucleus, PVN, paraventricular nucleus, RVLM, rostral ventrolateral medulla, CVLM, caudal ventrolateral medulla, + excitatory synapse (glutamate, acetylcholine or norepinephrine), - inhibitory synapse (GABA, $Y$-aminobutyric acid), $R$, potential modulation by receptor binding, I, potential modulation by enhancement of inhibitory GABA and NO signaling.

set reference point for blood pressure regulation (Irmak and Sizlan 2006) and inhibit the activity of RVLM through caudal ventrolateral medulla (CVLM) (Patel et al. 2001).

Second, GABA-ergic signalization is involved in the inhibition of PVN by SCN (Kalsbeek et al. 2000) and in the inhibition of RVLM by CVLM (Patel et al. 2001). Melatonin was reported to enhance GABA-ergic signalization (Wang et al. 2003), which may contribute to inhibition of these nuclei and subsequent decrease in sympathetic tone.

Third, NO formation was shown to potentiate GABA-ergic inhibitory effects in PVN (Rossi et al. 2004) and RVLM (Patel et al. 2001). The potential of melatonin to increase NO availability may additionally augment inhibition in these areas (Fig. 3).

\section{The effect of melatonin on cardiovascular remodeling}

Beside the effects of melatonin on blood pressure, an important question remains whether melatonin treatment may beneficially modify the deterioration of organ structure and function associated with hypertension, coronary artery disease or dyslipidemia.

\section{The effect of melatonin on vascular structure}

Although extensive attention was devoted to the modulation of vascular function by melatonin, the effect of melatonin on vascular morphology was less intensively investigated. Nevertheless, improved NO production and decreased oxidative load after melatonin administration (Anwar et al. 2001) may lead to prevention of endothelial structural alterations. Most promising results were obtained in models with altered metabolic conditions, which produce pronounced endothelial damage. In rats on high-fat diet melatonin administration attenuated atheromatous changes in arteries along with the normalization of blood pressure, body weight, blood glucose, improvement of antioxidant capacity and lipid profile (Hussein et al. 2007). In hypertriglyceridemic rats, melatonin prevented intimal infiltration by foam cells induced by cholesterol in association with modified plasmatic fatty acid composition (Pita et al. 2002). The prevention of endothelial damage may help to explain more effective blood pressure reduction in type 1 diabetic patients than in controls (Cavallo et al. 2004). However, under the conditions of less compromised endothelium melatonin can also improve endothelial function. The prevention of early atheromatous changes and endothelial damage with direct impact on arterial function may help several organs especially the brain to cope with ischemia-reperfusion injury or other pathological conditions.

Deficit of melatonin induced by pinealectomy decreased cross-sectional area, attenuated compliance and increased stiffness of rat cerebral arterioles, whereas lowdose melatonin treatment prevented the development of these alterations (Regrigny et al. 2001). Beside this fact, there is lack of other evidence for modulation of medial structure by melatonin. Yet, there are several attributes of melatonin, which could potentially lead to improvement of vascular remodeling. Numerous melatonin-induced changes such as attenuation of hemodynamic overload, decrease in sympathetic output (Girouard et al. 2003), 
reduction of oxidative load (Tan et al. 2007), increase in bioavailability of NO, which has antiproliferative and antiproteosynthetic effects (Šimko and Šimko 2000) as well as reduction of serum cholesterol levels and lipid profile normalization (Wakatsuki et al. 2001, Sandyk and Awerbuch 1994) encourage future investigations of the modulation of vascular structure by melatonin.

\section{The effect of melatonin on left ventricular hypertrophy}

Melatonin prevented cardiac hypertrophy in hyperthyroid rats along with reduced oxidative load and altered expression of metabolically important genes (Ghosh et al. 2007). This study indicates that the effect of melatonin on hemodynamic overload, NO availability, free radicals and lipid profile may modify myocardial remodeling as well. On the other hand, despite the reduction of blood pressure melatonin failed to ameliorate left ventricular hypertrophy in SHR (Šimko et al. 2006), but some promising results were obtained in melatonindeficient models. Pinealectomy increased heart weight and fibrosis (Mizrak et al. 2004, Sahna et al. 2002) and continuous light increased collagen types I/III ratio (Paulis et al. 2007). Since the increase in heart weight was proportional to the increase in body weight (Sahna et al. 2002, Paulis et al. 2007) and the gain in heart weight did not correlate with blood pressure rise (Sahna et al. 2002), the hemodynamic load was probably not the decisive factor for the development of these alterations. Pinealectomy was also associated with several metabolic alterations including enhanced isoproterenol-induced lipolysis in rats (Borges-Silva et al. 2005), hypercholesterolemia and transient hypertriglyceridemia in type 2 diabetic rats (Nishida et al. 2003) and hypercholesterolemia and hyperlipidemia in rabbits (Damian 1976). Insufficient effect of melatonin on food efficiency and growth factors and insulin levels (WoldenHanson et al. 2000) in melatonin-deficient conditions may participate in the development of cardiac remodeling. It can be expected that blood pressure reducing and metabolic impact of melatonin may be especially beneficial against cardiovascular damage associated with metabolic syndrome.

\section{Melatonin and cardiac reperfusion injury}

There is evidence for cardioprotective effect of melatonin against ischemia-reperfusion injury. Melatonin reduced the infarct size/risk area (Chen et al. 2003, Sahna et al. 2005) and the incidence of reperfusion arrhythmias (Lagneux et al. 2000, Lee et al. 2002, Sahna et al. 2002).
Since ischemia is associated with formation of oxygen free radicals from the residual molecular oxygen (Jennings et al. 2001), the cardioprotective effect is probably associated with melatonin ability to scavenge free radicals (Allegra et al. 2003, Sahna et al. 2005) and to induce the expression of antioxidant enzymes (Reiter 2000). Melatonin was even more efficient in reducing the severity of reperfusion arrhythmias than the antioxidant vitamin C (Tan et al. 1998). There are following possible explanations for the especially high effectiveness of melatonin in preventing reperfusion injury of various organs:

First, beside antioxidant action other mechanisms take part in the protective effect of melatonin. Melatonin was reported to decrease cytosolic calcium in cardiomyocytes (Chen et al. 1993) what could modify the electrical stability of the myocardium and contribute to protective action of melatonin against ischemia-induced arrhythmias (Lagneaux et al. 2000). These changes in cytosolic calcium may result from stimulation of melatonin receptors, which are present in cardiomyocytes (Pang et al. 2002) or from other nonspecific melatonin effects like direct interaction with calmodulin (Turjanski et al. 2004), inhibition of $\mathrm{Ca}^{2+}$ channels (Satake et al. 1986, Shibata et al. 1989) or calcium pump stimulation (Chen et al. 1993).

Second, the antioxidant action of melatonin is extraordinary high. Melatonin takes a special place among other antioxidants. Melatonin does not undergo redox cycling (Tan et al. 2000), enhances the activity of antioxidant enzymes (Antolin et al. 1996, BarlowWalden et al. 1995), and its primary, secondary and tertiary metabolites also posses high free radical scavenging activity (Tan et al. 2007). Most importantly, melatonin may penetrate lipid cell membrane (Mor et al. 1999) and act as intracellular antioxidant unleashing its scavenging properties.

\section{Conclusions}

Melatonin was shown to be involved in several cardiovascular pathologies and its therapeutic use is being considered (Šimko and Paulis 2007). However, the underlying mechanisms of melatonin protection within the cardiovascular system are not properly understood.

Although melatonin decreases peripheral resistance, results of experiments on isolated arteries are partly controversial and vasodilatation cannot be completely explained only by activation of second 
messenger cascades associated with melatonin receptors. Thus, more sophisticated approach should be taken into consideration:

On the periphery, receptor-mediated vasoconstriction on vascular smooth cells might be counterbalanced by receptor-mediated NO release from endothelial cells, which is further enhanced by antioxidant properties of melatonin.

In the central nervous system, enhancement of GABA-ergic signaling, scavenging free radicals and augmentation of NO availability may substantially participate in the reduction of sympathetic output resulting in blood pressure decrease observed in vivo.

Additionally to the reduction of blood pressure, melatonin may be expected to prevent target cardiovascular damage as well. Melatonin protects heart against ischemia-reperfusion injury by its extraordinary antioxidant activity and its antilipidemic effects may attenuate undesirable vascular alterations.

Further investigation of these mechanisms may extend the knowledge on pathogenetic mechanisms of cardiovascular diseases, provide additional explanation for their circadian and seasonal variability and potentially generate new impulses for the development of novel therapeutic approaches.

\section{Acknowledgements}

We highly appreciate the help of Dr. Josef Zicha in carefully reading the manuscript and contributing with valuable ideas. This work was supported by the grant UK 29/2007, VEGA 1/3429/06, 2/6148/26, and APVT $51-027404$.

\section{References}

ABETE P, BIANCO S, CALABRESE C, NAPOLI C, CACCIATORE F, FERRARA N, RENGO F: Effects of melatonin in isolated rat papillary muscle. FEBS Lett 412: 79-85, 1997.

ALLEGRA M, REITER RJ, TAN DX, GENTILE C, TESORIERE L, LIVREA MA: The chemistry of melatonin's interaction with reactive species. J Pineal Res 34: 1-10, 2003.

ANTOLIN I, RODRIGUEZ C, SAINZ RM, MAYO JC, URIA H, KOTLER ML, RODRIGUEZ-COLUNGA MJ, TOLIVIA D, MENENDEZ-PELAEZ A: Neurohormone melatonin prevents cell damage: effect on gene expression for antioxidant enzymes. FASEB J 10: 882-890, 1996.

ANWAR MM, MEKI AR, RAHMA HH: Inhibitory effects of melatonin on vascular reactivity: possible role of vasoactive mediators. Comp Biochem Physiol C Toxicol Pharmacol 130: 357-367, 2001.

ARANGINO S, CAGNACCI A, ANGIOLUCCI M, VACCA AMB, LONGU G, VOLPE A, MELIS GB: Effects of melatonin on vascular reactivity, catecholamine levels, and blood pressure in healthy men. Am J Cardiol 83: 1471-1419, 1999.

BALTATU O, AFECHE SC, DOS SANTOS SHJ, CAMPOS LA, BARBOSA R, MICHELINI LC, BADER M, CIPOLLA-NETO J: Locally synthesized angiotensin modulates pineal melatonin generation. J Neurochem $\mathbf{8 0}$ : 328-334, 2002.

BARLOW-WALDEN LR, REITER RJ, ABE M, PABLOS M, MENENDEZ-PELAEZ A, CHEN LD, POEGGELER B: Melatonin stimulates brain glutathione peroxidase activity. Neurochem Int 26: 497-502, 1995.

BLANCHARD B, POMPON D, DUCROCQ C: Nitrosation of melatonin by nitric oxide and peroxynitrite. J Pineal Res 29: 184-192, 2000.

BORGES-SILVA CN, FONSECA-ALANIZ MH, ALONSO-VALE MI, TAKADA J, ANDREOTTI S, PERES SB, CIPOLLA-NETO J, PITHON-CURI TC, LIMA FB: Reduced lipolysis and increased lipogenesis in adipose tissue from pinealectomized rats adapted to training. J Pineal Res 39: 178-184. 2005.

BRIAUD SA, ZHANG BL, SANNAJUST F: Continuous light exposure and sympathectomy suppress circadian rhythm of blood pressure in rats. J Cardiovasc Pharmacol Ther 9: 97-105, 2004.

BROMME HJ, MORKE W, PESCHKE D, EBELT H, PESCHKE D: Scavenging effect of melatonin on hydroxyl radicals generated by alloxan. $J$ Pineal Res 29: 201-208, 2000.

BROWN GM, BAR-OR A, GROSSI D, KASHUR S, JOHANNSON E, YIE SM: Urinary 6-sulphatoxymelatonin, an index of pineal function in the rat. J Pineal Res 10: 141-147, 1991.

BRUGGER P, MARKTL W, HEROLD M: Impaired nocturnal secretion of melatonin in coronary heart disease. Lancet 345: $1408,1995$. 
BRYDON L, ROKA F, PETIT L, DE COPPET P, TISSOT M, BARRETT P, MORGAN PJ, NANOFF C, STROSBERG AD, JOCKERS R: Dual signaling of human Mella melatonin receptors via $\mathrm{G}_{\mathrm{i} 2}, \mathrm{G}_{\mathrm{i} 3}$, and $\mathrm{G}_{\mathrm{q} / 11}$ proteins. Mol Endocrinol 13: 2025-2038, 1999.

BUIJS RM, WORTEL J, VAN HEERIKHUIZE JJ, FEENSTRA MG, TER HORST GJ, ROMIJN HJ, KALSBEEK A: Anatomical and functional demonstration of a multisynaptic suprachiasmatic nucleus adrenal (cortex) pathway. Eur J Neurosci 11: 1535-1544, 1999.

CAGNACCI A, ARANGINO S, ANGIOLUCCI M, MASCHIO E, LONGU G, MELIS GB: J Potentially beneficial cardiovascular effects of melatonin administration in women. J Pineal Res 22: 16-19, 1997.

CAGNACCI A, ARANGINO S, ANGIOLUCCI M, MASCHIO E, A MELIS GB: Influences of melatonin administration on the circulation of women. Am J Physiol 274: R335-R338, 1998.

CAGNACCI A, ARANGINO S, ANGIOLUCCI M, MELIS GB, FACCHINETTI F, MALMUSI S, VOLPE A: Effect of exogenous melatonin on vascular reactivity and nitric oxide in postmenopausal women: role of hormone replacement therapy. Clin Endocrinol (Oxf) 54: 261-266, 2001.

CANO G, SVED AF, RINAMAN L, RABIN BS, CARD JP: Characterization of the central nervous system innervation of the rat spleen using viral transneuronal tracing. J Comp Neurol 439: 1-18, 2001.

CANO G, CARD JP, SVED AF: Dual viral transneuronal tracing of central autonomic circuits involved in the innervation of the two kidneys in rat. J Comp Neurol 471: 462-481, 2004.

CAPSONI S, VISWANATHAN M, DE OLIVEIRA AM, SAAVEDRA JM: Characterization of melatonin receptors and signal transduction system in rat arteries forming the circle of Willis. Endocrinology 135: 373-378, 1994.

CAVALLO A, DANIELS SR, DOLAN LM, BEAN JA, KHOURY JC: Blood pressure-lowering effect of melatonin in type 1 diabetes. $J$ Pineal Res 36: 262-266, 2004.

CHEN LD, TAN DX, REITER RJ, YAGA K, POEGGELER B, KUMAR P, MANCHESTER LC, CHAMBERS JP: In vivo and in vitro effects of the pineal gland and melatonin on $\left[\mathrm{Ca}^{2+}+\mathrm{Mg}^{2+}\right]$-dependent ATPase in cardiac sarcolemma. J Pineal Res 14: 178-183, 1993.

CHEN Z, CHUA CC, GAO J, HAMDY RC, CHUA BH: Protective effect of melatonin on myocardial infarction. Am $J$ Physiol 284: H1618-H1624, 2003.

CHO S, JOH TH, BAIK HH, DIBINIS C, VOLPE BT: Melatonin administration protects CA1 hippocampal neurons after transient forebrain ischemia in rats. Brain Res 755: 335-338, 1997.

COOTE JH, YANG Z, PYNER S, DEERING J: Control of sympathetic outflows by the hypothalamic paraventricular nucleus. Clin Exp Pharmacol Physiol 25: 461-463, 1998.

COSTA EJ, LOPES RH, LAMY-FREUND MT: Permeability of pure lipid bilayers to melatonin. J Pineal Res 19: 123$126,1995$.

CUNNANE SC, MANKU MS, OKA M, HORROBIN DF: Enhanced vascular reactivity to various vasoconstrictor agents following pinealectomy in the rat: role of melatonin. Can J Physiol Pharmacol 58: 287-293, 1980.

DAMIAN E: The role of the pineal gland in the lipid metabolism. Endocrinologie 16: 179-189, 1978.

DEMURO RL, NAFZIGER AN, BLASK DE, MENHINICK AM, BERTINO JS JR: The absolute bioavailability of oral melatonin. J Clin Pharmacol 40: 781-784, 2000.

DOMINGUEZ-RODRIGUEZ A, ABREU-GONZALEZ P, GARCIIA MJ, SANCHEZ J, MARRERO F, DE ARMASTRUJILLO D: Decreased nocturnal melatonin levels during acute myocardial infarction. J Pineal Res 33: 248$252,2002$.

DOOLEN S, KRAUSE DN, DUBOCOVICH ML, DUCKLES SP: Melatonin mediates two distinct responses in vascular smooth muscle. Eur J Pharmacol 345: 67-69, 1998.

DUBOCOVICH ML: Melatonin receptors: are there multiple subtypes? Trends Pharmacol Sci 16: 50-56, 1995.

DUBOCOVICH ML, CARDINALI DP, GUARDIOLA-LEMAITRE B, HAGAN RM, KRAUSE DN, SUGDEN D, VANHOUTTE PM, YOCCA FD: Melatonin receptors. The IUPHAR Compendium of Receptor Characterization and Classification. IUPHAR Media, London, 1998, pp 187-193.

DUNCAN MJ, TAKAHASHI JS, DUBOCOVICH ML: Characteristics and autoradiographic localization of 2-[ $\left[{ }^{125} \mathrm{I}\right]$ iodomelatonin binding sites in Djungarian hamster brain. Endocrinology 125: 1011-1018, 1989. 
EKMEKCIOGLU C, HASLMAYER P, PHILIPP C, MEHRABI MR, GLOGAR HD, GRIMM M, LEIBETSEDER VJ, THALHAMMER T, MARKTL W: Expression of the MT1 melatonin receptor subtype in human coronary arteries. J Recept Signal Transduct Res 21: 85-91, 2001.

EKMEKCIOGLU C, THALHAMMER T, HUMPELER S, MEHRABI MR, GLOGAR HD, HOLZENBEIN TH, MARKOVIC O, LEIBETSEDER VJ, STRAUSS-BLASCHE G, MARKTL W: The melatonin receptor subtype MT2 is present in the human cardiovascular system. $J$ Pineal Res 35: 40-44, 2003.

GIROUARD H, CHULAK CH, LEJOSSEC M, LAMONTAGNE D, DE CHAMPLAIN J: Vasorelaxant effects of the chronic treatment with melatonin on mesenteric artery and aorta of spontaneously hypertensive rats. J Hypertens 19: 1369-1377, 2001.

GIROUARD H, CHULAK CH, LEJOSSEC M, LAMONTAGNE D, De CHAMPLAIN J: Chronic antioxidant treatment improves sympathetic functions and $\beta$-adrenergic pathway in the spontaneously hypertensive rats. J Hypertens 21: 179-188, 2003.

GiROUARD H, DENAUlT C, CHULAK C, De CHAMPLAIN J: Treatment by N-acetylcysteine and melatonin increases cardiac baroreflex and improves antioxidant reserve. Am J Hypertens 17: 947-954, 2004.

GIROTTI L, LAGO M, IANOVSKY O, ELIZARI MV, DINI A, LLORET SP, ALBORNOZ LE, CARDINALI DP: Low urinary 6-sulfatoxymelatonin levels in patients with severe congestive heart failure. Endocrine 22: 245248, 2003.

GITTO E, TAN DX, REITER RJ, KARBOWNIK M, MANCHESTER LC, CUZZOCREA S, FULIA F, BARBERI I: Individual and synergistic antioxidative actions of melatonin: studies with vitamin $\mathrm{E}$, vitamin $\mathrm{C}$, glutathione and desferrioxamine (desferoxamine) in rat liver homogenates. $J$ Pharm Pharmacol 53: 1393-1401, 2001.

GHOSH G, DE K, MAITY S, BANDYOPADHYAY D, BHATTACHARYA S, REITER RJ, BANDYOPADHYAY A: Melatonin protects against oxidative damage and restores expression of GLUT4 gene in the hyperthyroid rat heart. J Pineal Res 42: 71-82, 2007.

GONCHARUK VD, HEERIKHUIZE JV, DAI JP, SWAAB DF, BUIJS RM: Neuropeptide changes in the suprachiasmatic nucleus in primary hypertension indicate functional impairment of the biological clock. J Comp Neurol 431: 320-330, 2001.

GUZZETTI S, DASSI S, PECIS M, CASATI R, MASU AM, LONGONI P, TINELLI M, CERUTTI S, PAGANI M, MALLIANI A: Altered pattern of circadian neuronal control of heart period in mild hypertension. $J$ Hypertens 9: 831-838, 1991.

HARLOW HJ: Influence of the pineal gland and melatonin on blood flow and evaporative water loss during heat stress in rats. J Pineal Res 4: 147-159, 1987.

HOLMES SW, SUGDEN D: The effect of melatonin on pinealectomy-induced hypertension in the rat. BrJ Pharmacol 56: 360P-361P, 1976.

HUSSEIN MR, AHMED OG, HASSAN AF, AHMED MA: Intake of melatonin is associated with amelioration of physiological changes, both metabolic and morphological pathologies associated with obesity: an animal model. Int J Exp Pathol 88: 19-29, 2007.

IANAS O, OLINESCU R, BADESCU I: Melatonin involvement in oxidative processes. Endocrinologie 29: 147-153, 1991.

IRMAK MK, SIZLAN A: Essential hypertension seems to result from melatonin-induced epigenetic modifications in area postrema. Med Hypotheses 66: 1000-1007, 2006.

JENNINGS RB, SEBBAG L, SCHWARTZ LM, CRAGO MS, REIMER KA: Metabolism of preconditioned myocardium: effect of loss and reinstatement of cardioprotection. J Mol Cell Cardiol 33: 1571-1588, 2001.

JONAS M, GARFINKEL D, ZISAPEL N, LAUDON M, GROSSMAN E: Impaired nocturnal melatonin secretion in non-dipper hypertensive patients. Blood Press 12: 19-24, 2003.

K-LAFLAMME A, WU L, FOUCART S, DE CHAMPLAIN J: Impaired basal sympathetic tone and $\alpha_{1}$-adrenergic responsiveness in association with the hypotensive effect of melatonin in spontaneously hypertensive rats. $\mathrm{Am}$ J Hypertens 11: 219-229, 1998.

KALSBEEK A, GARIDOU ML, PALM IF, VAN DER VLIET J, SIMONNEAUX V, PEVET P, BUIJS RM: Melatonin sees the light: blocking GABA-ergic transmission in the paraventricular nucleus induces daytime secretion of melatonin. Eur J Neurosci 12: 3146-3154, 2000. 
KAWASHIMA K, MIWA Y, FUJIMOTO K, OOHATA H, NISHINO H, KOIKE H: Antihypertensive action of melatonin in the spontaneously hypertensive rat. Clin Exp Hypertens A 9: 1121-1131, 1987.

KENNAWAY DJ AND VOULTSIOS A: Circadian rhythm of free melatonin in human plasma. $J$ Clin Endocrinol Metab 83: 1013-1015, 1998.

KLEIN DC, WELLER JL: Rapid light-induced decrease in pineal serotonin N-acethyltransferase activity. Science 177: 532-533, 1972.

KLEIN DC, SUGDEN D, WELLER JL: Postsynaptic alpha-adrenergic receptors potentiate the beta-adrenergic stimulation of pineal serotonin N-acetyltransferase. Proc Natl Acad Sci USA 80: 599-603, 1983.

KOJŠOVÁ S, JENDEKOVÁ L, ZICHA J, KUNEŚ J, ANDRIANTSITOHAINA R, PECHÁŇOVÁ O: The effect of different antioxidants on nitric oxide production in hypertensive rats. Physiol Res 55 (Suppl 1): S3-S16, 2006.

LAGNEUX C, JOYEUX M, DEMENGE P, RIBUOT C, GODIN-RIBUOT D: Protective effects of melatonin against ischemia-reperfusion injury in the isolated rat heart. Life Sci 66: 503-509, 2000.

LEE YM, CHEN HR, HSIAO G, SHEU JR, WANG JJ, YEN MH: Protective effects of melatonin on myocardial ischemia/reperfusion injury in vivo. J Pineal Res 33: 72-80, 2002.

LERNER AB, CASE JD, TAKAHASHI Y, LEE TH, MORI W: Isolation of melatonin, a pineal factor that lightens melanocytes. J Am Chem Soc 80: 2587, 1958.

MALPAUX B, SKINNER DC, MAURICE F: The ovine pars tuberalis does not appear to be targeted by melatonin to modulate luteinizing hormone secretion, but may be important for prolactin release. J Neuroendocrinol 7: 199206, 1995.

MALPAUX B, MIGAUD M, TRICOIRE H, CHEMINEAU P: Biology of mammalian photoperiodism and the critical role of the pineal gland and melatonin. $J$ Biol Rhythms 16: 336-347, 2001.

MASANA MI, DOOLEN S, ERSAHIN C, AL-GHOUL WM, DUCKLES SP, DUBOCOVICH ML, KRAUSE DN: $\mathrm{MT}_{2}$ melatonin receptors are present and functional in rat caudal artery. $J$ Pharmacol Exp Ther 302: 12951302, 2002.

MIZRAK B, PARLAKPINAR H, ACET A, TURKOZ Y: Effects of pinealectomy and exogenous melatonin on rat hearts. Acta Histochem 106: 29-36, 2004.

MONROE KK, WATTS SW: The vascular reactivity of melatonin. Gen Pharmacol 30: 31-35, 1998.

MOORE RY: Neural control of the pineal gland. Behav Brain Res 73: 125-30, 1996.

MOR M, PLAZZI PV, SPADONI G, TARZIA G: Melatonin. Curr Med Chem 6: 501-518, 1999.

NAKANO Y, OSHIMA T, OZONO R, HIGASHI Y, SASAKI S, MATSUMOTO T, MATSUURA H, CHAYAMA K, KAMBE M: Non-dipper phenomenon in essential hypertension is related to blunted nocturnal rise and fall of sympatho-vagal nervous activity and progress in retinopathy. Auton Neurosci 88: 181-186, 2001.

NELSON CS, MARINO JL, ALLEN CN: Melatonin receptors activate heteromeric G-protein coupled Kir3 channels. Neuroreport 7: 717-720, 1996.

NISHIDA S, SATO R, MURAI I, NAKAGAWA S: Effect of pinealectomy on plasma levels of insulin and leptin and on hepatic lipids in type 2 diabetic rats. J Pineal Res 35: 251-256, 2003.

NODA Y, MORI A, LIBURDY R, PACKER L: Melatonin and its precursors scavenge nitric oxide. $J$ Pineal Res 27: 159-163, 1999.

OKATANI Y, WAKATSUKI A, WATANABE K, TANIGUCHI K, FUKAYA T: Weak vasoconstrictor activity of melatonin in human umbilical artery: relation to nitric oxide-scavenging action. Eur $J$ Pharmacol 417: 125$129,2001$.

PANG CS, BROWN GM, TANG PL, CHENG KM, PANG SF: 2-[ $\left.{ }^{125} \mathrm{I}\right]$ iodomelatonin binding sites in the lung and heart: a link between the photoperiodic signal, melatonin, and the cardiopulmonary system. Biol Signals 2: 228-236, 1993.

PANG CS, XI SC, BROWN GM, PANG SF, SHIU SY: 2[125I]Iodomelatonin binding and interaction with betaadrenergic signaling in chick heart/coronary arteryphysiology. J Pineal Res 32: 243-252, 2002.

PATEL KP, LI YF, HIROKA Y: Role of nitric oxide in central sympathetic outflow. Exp Biol Med 226: 814-824, 2001.

PAULIS L, KRAJČÍROVIČOVÁ K, JANEGA P, KOJŠOVÁ S, CSIZMADIOVÁ Z, PECHÁŇOVÁ O, ŠIMKO F: The antihypertensive action of melatonin in spontaneously hypertensive rats: comparison with spironolactone. Hypertension 48: 776, 2006. 
PAULIS L', VAŽAN R, ŠIMKO F, PECHÁŇOVÁ O, STYK J, BABÁL P, JANEGA P: Morphological alterations and NO-synthase expression in the heart after continuous light exposure of rats. Physiol Res 56 (Suppl 2), in press, 2007.

PECHÁŇOVÁ O, ZICHA J, PAULIS L, ZENEBE W, DOBEŠOVÁ Z, KOJŠOVÁ S, JENDEKOVÁ L, SLÁDKOVÁ M, DOVINOVÁ I, ŠIMKO F, KUNEŠ J: The effect of N-acetylcysteine and melatonin in adult spontaneously hypertensive rats with established hypertension. Eur J Pharmacol 561: 129-136, 2007.

PIERI C, MARRA M, MORONI F, RECCHIONI R, MARCHESELLI F: Melatonin: a peroxyl radical scavenger more effective than vitamin E. Life Sci 55: PL271-PL276, 1994.

PITA ML, HOYOS M, MARTIN-LACAVE I, OSUNA C, FERNANDEZ-SANTOS JM, GUERRERO JM: Long-term melatonin administration increases polyunsaturated fatty acid percentage in plasma lipids of hypercholesterolemic rats. $J$ Pineal Res 32: 179-186, 2002.

POGAN L, BISSONNETTE P, PARENT L, SAUVE R: The effects of melatonin on $\mathrm{Ca}^{2+}$ homeostasis in endothelial cells. J Pineal Res 33: 37-47, 2002.

PYNER S, COOTE JH: Identification of branching paraventricular neurons of the hypothalamus that project to the rostroventrolateral medulla and spinal cord. Neuroscience 100: 549-556, 2000.

REGRIGNY O, DELAGRANGE P, SCALBERT E, ATKINSON J, CHILLON JM: Melatonin increases pial artery tone and decreases the lower limit of cerebral blood flow autoregulation. Fundam Clin Pharmacol 15: 233238, 2001.

REITER RJ: Pineal melatonin: cell biology of its synthesis and of its physiological interactions. Endocr Rev 12: 151180, 1991.

REITER RJ: Melatonin: Lowering the high price of free radicals. News Physiol Sci 15: 246-250, 2000.

REITER RJ, TAN DX, LEON J, KILIC U, KILIC E: When melatonin gets on your nerves: its beneficial actions in experimental models of stroke. Exp Biol Med 230: 104-117, 2005.

REPPERT SM, WEAVER DR, RIVKEES SA, STOPA EG: Putative melatonin receptors in a human biological clock. Science 242: 78-83, 1988.

REPPERT SM, WEAVER DR, GODSON C: Melatonin receptors step into the light: cloning and classification of subtypes. Trends Pharmacol Sci 17: 100-102, 1996.

RIBELAYGA C, PEVET P, SIMONNEAUX V: Adrenergic and peptidergic regulations of hydroxyindole-Omethyltransferase activity in rat pineal gland. Brain Res 777: 247-501, 1997.

ROSSI NF, BLACK SM, TELEMAQUE-POTTS S, CHEN H: Neuronal Nitric Oxide Synthase Activity in the Paraventricular Nucleus Buffers Central Endothelin-1- induced Pressor Response and Vasopressin Secretion. J Cardiovasc Pharmacol 44: S283-S288, 2004.

SAHNA E, OLMEZ E, ACET A: Effects of physiological and pharmacological concentrations of melatonin on ischemia-reperfusion arrhythmias in rats: can the incidence of sudden cardiac death be reduced? J Pineal Res 32: 194-198, 2002.

SAHNA E, PARLAKPINAR H, OZTURK F, CIGREMIS Y, ACET A: The protective effects of physiological and pharmacological concentrations of melatonin on renal ischemia-reperfusion injury in rats. Urol Res 31: 188-93, 2003.

SAHNA E, PARLAKPINAR H, TURKOZ Y, ACET A: Protective effects of melatonin on myocardial ischemia/reperfusion induced infarct size and oxidative changes. Physiol Res 54: 491-495, 2005.

SANDYK R, AWERBUCH GI: The relationship between melatonin secretion and serum cholesterol in patients with multiple sclerosis. Int J Neurosci 76: 81-86, 1994.

SATAKE N, SHIBATA S, TAKAGI T: The inhibitory action of melatonin on the contractile response to 5-hydroxytryptamine in various isolated vascular smooth muscles. Gen Pharmacol 17: 553-558, 1986.

SCHEER FA, VAN DOORNEN LJP, BUIJS RM: Light and diurnal cycle affect human heart rate: possible role for the circadian pacemaker. J Biol Rhythms 14: 202-212, 1999.

SCHEER FA, TER HORST GJ, VAN DER VLIET J, BUIJS RM: Physiological and anatomic evidence for regulation of the heart by suprachiasmatic nucleus in rats. Am J Physiol 280: H1391-H1399, 2001.

SCHEER FA, KALSBEEK A, BUIJS RM: Cardiovascular control by the suprachiasmatic nucleus: neural and neuroendocrine mechanisms in human and rat. Biol Chem 384: 697-709, 2003. 
SCHEER FA, VAN MONTFRANS GA, VAN SOMEREN EJ, MAIRUHU G, BUIJS RM: Daily nighttime melatonin reduces blood pressure in male patients with essential hypertension. Hypertension 43: 192-197, 2004.

SEWERYNEK E, REITER RJ, MELCHIORRI D, ORTIZ GG, LEWINSKI A: Oxidative damage in the liver induced by ischemia-reperfusion: protection by melatonin. Hepatogastroenterology 43: 898-905, 1996.

SHIBATA S, SATAKE N, TAKAGI T, USUI H: Vasorelaxing action of melatonin in rabbit basilar artery. Gen Pharmacol 20: 677-680, 1989.

ŠIMKO F, ŠIMKO J: The potential role of nitric oxide in the hypertrophic growth of the left ventricle. Physiol Res 49: 37-46, 2000.

ŠIMKO F, PAULIS L: Melatonin as a potential antihypertensive treatment. J Pineal Res 42: 319-322, 2007.

ŠIMKO F, PAULIS L', KRAJČÍROVIČOVÁ K, JANEGA P, KOJŠOVÁ S, PECHÁŇOVÁ O: Comparison of captopril and melatonin on the heart remodeling in spontaneously hypertensive rats. J Hypertens 24 (Suppl 4): S340, 2006.

STOCKER SD, SIMMONS JR, STORNETTA RL, TONEY GM, GUYENET PG: Water deprivation activates a glutamatergic projection from the hypothalamic paraventricular nucleus to the rostral ventrolateral medulla. J Comp Neurol 494: 673-685, 2006.

TAN DX, MANCHESTER LC, REITER RJ, QI W, KIM SJ, EL-SOKKARY GH: Ischemia/reperfusion-induced arrhythmias in the isolated rat heart: prevention by melatonin. J Pineal Res 25: 184-191, 1998.

TAN DX, MANCHESTER LC, REITER RJ, QI WB, KARBOWNIK M, CALVO JR: Significance of melatonin in antioxidative defense system: reactions and products. Biol Signals Recept 9: 137-159, 2000.

TAN DX, MANCHESTER LC, TERRON MP, FLORES LJ, REITER RJ: One molecule, many derivatives: a neverending interaction of melatonin with reactive oxygen and nitrogen species? J Pineal Res 42: 28-42, 2007.

TURJANSKI AG, ESTRIN DA, ROSENSTEIN RE, MCCORMICK JE, MARTIN SR, PASTORE A, BIEKOFSKY RR, MARTORANA V: NMR and molecular dynamics studies of the interaction of melatonin with calmodulin. Protein Sci 13: 2925-2938, 2004.

TYLICKI L, RUTKOWSKI B, HORL WH: Antioxidants: a possible role in kidney protection. Kidney Blood Press Res 26: 303-314, 2003.

VANEČEK J, JANSKÝ L: Short days induce changes in specific melatonin binding in hamster median eminence and anterior pituitary. Brain Res 477: 387-390, 1989.

VANEČEK J, PAVLÍK A, ILLNEROVÁ H: Hypothalamic melatonin receptor sites revealed by autoradiography. Brain Res 435: 359-362, 1987.

VAŽAN R, STYK J, BÉDER I, PANCZA D: Effect of melatonin on the isolated heart in the standard perfusion conditions and in the conditions of calcium paradox. Gen Physiol Biophys 22: 41-50, 2003.

VAŽAN R, BÉDER I, STYK J: Melatonin and the heart. Cesk Fysiol 53: 29-33, 2004.

VISWANATHAN M, LAITINEN JT, SAAVEDRA JM: Expression of melatonin receptors in arteries involved in thermoregulation. Proc Natl Acad Sci USA 87: 6200-6203, 1990.

WALDHAUSER F, WALDHAUSER M, LIEBERMAN HR, DENG MH, LYNCH HJ, WURTMAN RJ: Bioavailability of oral melatonin in humans. Neuroendocrinology 39: 307-313, 1984.

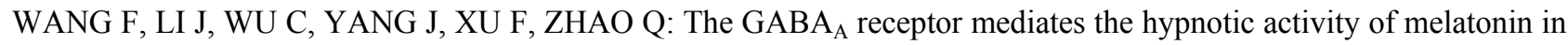
rats. Pharmacol Biochem Behav 74: 573-578, 2003.

WAKATSUKI A, OKATANI Y, IKENOUE N, KANEDA C, FUKAYA T: Effects of short-term melatonin administration on lipoprotein metabolism in normolipidemic postmenopausal women. Maturitas 38: 171-177, 2001.

WEEKLEY LB: Melatonin-induced relaxation of rat aorta: interaction with adrenergic agonists. J Pineal Res 11: 28-34, 1991.

WEEKLEY LB: Effects of melatonin on isolated pulmonary artery and vein: role of the vascular endothelium. Pulm Pharmacol 6: 149-154, 1993.

WILLIAMS LM, MORGAN PJ: Demonstration of melatonin-binding sites on the pars tuberalis of the rat. J Endocrinol 119: R1-R3, 1988.

WILLIAMS LM, HANNAH LT, HASTINGS MH, MAYWOOD ES: Melatonin receptors in the rat brain and pituitary. J Pineal Res 19: 173-177, 1995. 
WITT-ENDERBY PA, DUBOCOVICH ML: Characterization and regulation of the human ML1A melatonin receptor stably expressed in Chinese hamster ovary cells. Mol Pharmacol 50: 166-174, 1996.

WOLDEN-HANSON T, MITTON DR, MCCANTS RL, YELLON SM, WILKINSON CW, MATSUMOTO AM, RASMUSSEN DD: Daily melatonin administration to middle-aged male rats suppresses body weight, intraabdominal adiposity, and plasma leptin and insulin independent of food intake and total body fat. Endocrinology 141: 487-497, 2000.

WU L, WANG R, DE CHAMPLAIN J: Enhanced inhibition by melatonin of a-adrenoceptorinduced aortic contraction and inositol phosphate production in vascular smooth muscle cells from spontaneously hypertensive rats. J Hypertens 16: 339-347, 1998.

WURTMAN RJ, AXELORD J, CHU EW: The relation between melatonin, a pineal substance, and the effects of light on the rat gonad. Ann N Y Acad Sci 117: 228-230, 1964.

ZANOBONI A, ZANOBONI-MUCIACCIA W: Experimental hypertension in pinealectomized rats. Life Sci 6: 23272331, 1967.

ZANOBONI A, FORNI A, ZANOBONI-MUCIACCIA W, ZANUSSI C: Effect of pinealectomy on arterial blood pressure and food and water intake in the rat. $J$ Endocrinol Invest 1: 125-130, 1978.

ZEMAN M, DULKOVÁ K, BADA V, HERICHOVÁ I: Plasma melatonin concentrations in hypertensive patients with the dipping and non-dipping blood pressure profile. Life Sci 76: 1795-1803, 2005.

\section{Corresponding author}

L. Paulis, Institute of Pathophysiology, School of Medicine, Comenius University, Sasinkova 4, 81108 Bratislava, Slovak Republic. Fax: +421-(0)2-59357601. E-mail: ludo@lfuk.sk 